\title{
Proses Berpikir dalam Memecahkan Masalah Logika Matematika Ditinjau dari Gaya Kognitif Field Independent dan Field Dependent
}

Ardi Dwi Susandi ${ }^{1}$, Santi Widyawati ${ }^{2}$

\author{
1) Univesitas Nahdlatul Ulama Cirebon, Indonesia \\ 2) Istitut Agama Islam Ma'arif NU (IAIMNU) Metro Lampung, Indonesia \\ Correspondence: $\triangle$ ardidwisusandi@yahoo.co.id
}

\begin{tabular}{|c|c|}
\hline Article Info & Abstract \\
\hline $\begin{array}{l}\text { Article History } \\
\text { Received : 07-05-2017 } \\
\text { Revised : 18-05-2017 } \\
\text { Accepted : 25-05-2017 }\end{array}$ & $\begin{array}{l}\text { This article is descriptive qualitative which describes the process of thinking of } \\
\text { students in solving mathematical problems on material combinations and } \\
\text { permutations. The data collection method in this study using GEFT tests to } \\
\text { determine cognitive styles of students, test description of material combinations }\end{array}$ \\
\hline $\begin{array}{l}\text { Keywords: } \\
\text { cognitive style; } \\
\text { thinking processes }\end{array}$ & $\begin{array}{l}\text { and permutations to obtain the thinking process of students, and interviews. Based } \\
\text { on cognitive style, students are grouped into } 2 \text { groups: FI and FD, and then } \\
\text { subsequently selected two students from two groups of students from the FI and } \\
\text { FD to give test of thinking ability and then interviews. Data analysis technique } \\
\text { used Miles and Huberman, data reduction, display, and conclusion } \\
\text { drawing/verification. Based on the analysis we concluded that students who have } \\
\text { the cognitive styles FI tend to have a conceptual thought process. Likewise, } \\
\text { students who have the cognitive style FD, these students are also likely to have a } \\
\text { conceptual thought process. The process of conceptual thinking is the thought } \\
\text { process which solves problems by using the concept that has been owned by the } \\
\text { results of studies. }\end{array}$ \\
\hline
\end{tabular}

\section{PENDAHULUAN}

Pendidikan merupakan usaha sadar untuk menyiapkan peserta didik melalui kegiatan bimbingan, pengajaran, dan latihan bagi peranannya di masa yang akan datang [1]. Sekolah sebagai suatu pendidikan formal, secara sistematis merencanakan bermacam-macam lingkungan, yakni lingkungan pendidikan yang menyediakan berbagai kesempatan bagi peserta didik untuk melakukan berbagai kegiatan belajar. Dengan berbagai kesempatan belajar itu, pertumbuhan dan perkembangan peserta didik diarahkan dan didorong ke arah pencapaian tujuan yang dicita-citakan. Lingkungan tersebut disusun dan ditata dalam suatu kurikulum, yang pada gilirannya dilaksanakan dalam bentuk proses pembelajaran [2]. Dalam Undang-Undang Nomor 20 tahun 2003 tentang Sistem Pendidikan Nasional, Bab 1 Pasal 1 ayat (1) dikemukakan bahwa pendidikan adalah usaha sadar dan terencana untuk mewujudkan suasana belajar dan proses pembelajaran agar peserta didik secara aktif mengembangkan potensi dirinya untuk memiliki kekuatan spiritual, keagamaan, pengendalian diri, kepribadian, kecerdasan, akhlak mulia, serta keterampilan yang diperlukan dirinya, masyarakat, bangsa, dan negara [3] [4].

Dunia pendidikan tidak terlepas dari pembelajaran karena pembelajaran merupakan proses membuat seseorang yang belum tahu menjadi tahu akan suatu permasalahan [5]. Pembelajaran itu sendiri juga sudah sangat ditekankan oleh Allah dalam firmannya dalam surat Al-Alaq [6]. Berdasarkan 
beberapa ayat tersebut Allah memberikan pengajaran bagi manusia untuk mengetahui apa yang tidak diketahui sebelumnya.

Matematika merupakan salah satu pelajaran yang mampu mengembangkan kreativitas peserta didik terutama dalam mengembangkan kreativitas berpikir seseorang [7]. Hal ini dikarenakan dalam mempelajari matematika, peserta didik dituntut untuk dapat mengembangkan pola berpikir kritis, sistematis, rasional, dan obyektif [8] [9]. Dengan memiliki kemampuan berpikir, maka mahasiswa akan lebih baik dalam memahami dan menguasai konsep-konsep matematika yang dipelajarinya.

Berdasarkan hasil prasurvey yang dilakukan peneliti pada mahasiswa semester IV program studi matematika Institut Agama Islam Ma'arif NU (IAIMNU) Metro lampung, terdapat mahasiswa mengalami kesulitan dalam memecahkan masalah matematika khususnya pada pokok bahasan logika matematika materi kombinasi dan permutasi. Dalam memecahkan masalah tersebut, ditemukan bahwa ada mahasiswa yang menunjukkan kemampuan yang sangat baik, ada mahasiswa yang menunjukan biasa saja, dan bahkan ada mahasiswa yang menunjukan mengalami kesulitan. Sehingga diperlukan strategi atau model pembelajaran yang sesuai dengan mahasiswa agar mampu memahami materi dan mampu menyelesaikan masalah yang diberikan dosen. Untuk mengetahui proses berpikir mahasiswa banyak ditinjau dari banyak dimensi karena sebagai manusia, mahasiswa adalah makhluk yang unik, dimana antara mahasiswa satu dengan yang lain berbeda dalam banyak dimensi. Tayler menyatkan bahwa pada dasarnya setiap individu berbeda satu dengan yang lain, dimensi-dimensi perbedaan individu antara lain adalah intelegensi, kemampuan berpikir logis, kreativitas, gaya kognitif, kepribadian, nilai, sikap dan minat [10]. Fakta ini menunjukan bahwa terdapat faktor kognitif yang berbeda antara peserta didik tersebut, yang mempengaruhi kemampuan dalam pemecahan suatu masalah dalam matematika.

Dalam belajar matematika dan menyelesaikan soal matematika, mahasiswa melakukan proses berpikir. Sehingga mahasiswa dapat sampai pada jawaban. Dalam pembelajaran matematika proses berpikir ini kurang mendapat perhatian dosen. Terkadang dosen hanya memperhatikan hasil akhir penyelesaian mahasiswa tanpa memperhatikan bagaimana sebenarnya mahasiswa itu dapat sampai pada jawaban itu. Jika jawaban mahasiswa berbeda dengan kunci biasanya dosen langsung menyalahkan jawaban tersebut tanpa menelusuri alasan mahasiswa mengapa jawabannya demikian. Padahal menurut Yulaelawati salah satu peran pendidik dalam pembelajaran matematika adalah membantu peserta didik mengungkapkan bagaimana proses yang berjalan dalam pikirannya ketika memecahkan masalah [11] [12].

Steiner dan Fresenborg mengatakan bahwa tugas pokok pengajaran matematika di sekolah adalah menjelaskan proses berfikir siswa dalam mempelajari matematika dengan tujuan memperbaiki pengajaran matematika di sekolah [13]. Oleh sebab itu, dengan mengetahui proses berfikir mahasiswa merupakan hal terpenting dalam pembelajaran matematika terutama dalam memecahkan masalah. Dengan mengetahui proses berfikir mahasiswa, maka dosen dapat merancang model pembelajaran yang efisien dan memudahkan mahasiswa dalam memahami konsep yang dipelajari [12].

Gaya kognitif sebagai bagian dari dimensi perbedaan individu mengacu pada karakteristik seseorang dalam menanggapi, memproses, menyimpan, berpikir, dan menggunakan informasi untuk menanggapi suatu tugas atau menanggapi berbagai jenis situasi lingkungan [14]. Dalam penelitian ini, Peneliti memilih fokus pada tipe gaya kognitif Field Independent (FI)-Field Dependent (FD). Perbedaan mendasar dari kedua gaya kognitif tersebut yaitu dalam hal bagaimana melihat suatu permasalahan. Berdasarkan beberapa penelitian di bidang psikologi, ditemukan bahwa individu dengan gaya kognitif 
FI cenderung lebih analitis dalam melihat suatu masalah dibandingkan individu dengan gaya kognitif FD. Dengan demikian, mahasiswa yang memiliki gaya kognitif FI tidak dipengaruhi lingkungan dan mampu mengatasi kesan, unsur, latar belakang yang menganggu. Sedangkan mahasiswa FD tidak dapat membebaskan diri dari unsur-unsur latar belakang yang mengganggu atau lebih dipengaruhi lingkungan. Karakteristik dasar dari kedua gaya kognitif tersebut sangat cocok untuk diterapkan dalam penelitian yang melibatkan proses berpikir dalam pemecahan masalah matematika.

\section{METODE PENELITIAN}

Jenis penelitian ini adalah penelitian deskriptif yang berusaha memaparkan data yang berasal dari subjek penelitian secara jelas. Penelitian ini dilaksanakan di IAIMNU Metro Lampung. Subjek dalam penelitian ini adalah mahasiswa semester IVA Prodi Pendidikan Matematika yang terdiri dari dua mahasiswa untuk masing-masing tipe gaya kognitif FI dan FD. Penentuan subjek dilakukan dengan menggunakan tes gaya kognitif GEFT. Dari hasil tes tersebut, dipilih mahasiswa yang memiliki kecenderungan terkuat terhadap masing-masing tipe gaya kognitif. Pengambilan subjek menggunakan teknik purposive sampling dengan kriteria sebagai berikut 1) dapat menkomunikasikan ide dengan baik secara tertulis atau lisan; 2) memiliki kemampuan pada masing-masing tipe gaya kognitif. Pemilihan subjek sesuai dengan kriteria diperoleh dari informasi dosen pengampu mata kuliah matematika diskrit di semester tersebut.

Teknik pengumpulan data yang digunakan dalam penelitian ini adalah tes, wawancara, dan dokumentasi. Instrumen tes yang digunakan adalah Tes Group Embedded Figure Test (GEFT)[15]. Instrumen GEFT terdiri dari 25 soal yang terbagi menjadi tiga bagian. Bagian pertama terdiri dari 7 soal, bagian kedua dan ketiga masing-masing terdiri dari 9 soal. Bagian pertama merupakan tahap latihan, bagian kedua dan ketiga merupakan tahap ujian dan penilaian. Total waktu yang diberikan untuk mengerjakan seluruh soal adalah 12 menit. Untuk bagian pertama, mahasiswa memiliki waktu 2 menit, sedangkan untuk bagian kedua dan ketiga waktu masing-masing 5 menit. Ketentuan penilaian dari GEFT adalah untuk setiap nomor yang dijawab benar diberi skor 1 dan jawaban salah skor 0. Jika mahasiswa tidak dapat menyelesaikan sesuai waktu yang ditentukan, maka soal tersebut dianggap salah dan diberi skor 0. Dengan demikian rentang skor yang diperoleh antara 0 sampai 18. Pedoman penskoran menurut Kepner dan Neimark adalah jika mahasiswa yang memperoleh skor $\leq 9$ memiliki gaya kognitif FD sedangkan skor $>9$ memiliki gaya kognitif FI. Instrumen GEFT merupakan instrumen baku yang digunakan untuk mengukur gaya kognitif, oleh karena itu peneliti tidak melakukan validasi dan uji coba instrumen GEFT. Selain itu, instrumen GEFT sudah pernah diujicobakan oleh Ismanu dan Cahyowati.

Tes uraian digunakan dalam penelitian ini karena untuk mempermudah peneliti mengetahui kesulitan mahasiswa terhadap materi kombinasi dan permutasi melelui respon jawaban dalam menjawab tes. Penilaian dari hasil tes ini berdasarkan langkah-langkah dalam menyelesaikan soal. Tes uraian ini terdiri dari 2 butir soal yang dikerjakan mahasiswa selama 30 menit materi kombinasi dan permutasi. Penyusunan butir-butir soal ini mengacu pada kesulitan belajar yang dialami mahasiswa pada materi kombinasi dan permutasi. Sebelum tes digunakan dalam penelitian, terlebih dahulu instrumen penelitian berupa tes tertulis ini divalidasi dengan validasi ahli (dosen ahli) agar instrumennya valid dan data yang diperoleh sesuai dengan harapan. Validasi ini dilakukan dengan pertimbangan 1) kesesuaian soal dengan kompetensi dasar dan indikator; 2) kesesuaian soal dengan kriteria tingkat proses berpikir; 3) ketepatan 
penggunaan kata/Bahasa; 4) soal tidak menimbulkan penafsiran ganda; 5) kejelasan yang diketahui dan ditanyakan.

Selanjutnya teknik wawancara yang digunakan adalah wawancara terstruktur dengan mencatat pokok-pokok pertanyaan yang akan diberikan. Untuk memaksimalkan hasil wawancara peneliti menggunakan alat perekam berupa video, tujuannya untuk mengantisipasi keterbatasan peneliti dalam mengingat informasi pada saat wawancara berlangsung. Selain tes dan wawancara, instrumen selanjutnya adalah dokumentasi. Dokumentasi adalah alat bantu yang digunakan untuk mengumpulkan data-data yang berupa dokumen seperti foto-foto kegiatan dan transkrip wawancara.

Teknik analisis data yang digunakan dalam penelitian ini adalah analisis data model Miles dan Huberman. Miles dan Huberman mengemukakan bahwa aktivitas yang dilakukan dalam penelitian kualitatif dilakukan dengan secara interaktif dan berlangsung secara terus menerus sampai tuntas, sehingga data tersebut sudah jenuh. Aktivitas dalam analisis data, yaitu data reduction, display, dan conclusion drawing/verification [16].

\section{HASIL DAN PEMBAHASAN}

Pada bagian ini akan dibahas mengenai hasil penelitian yang diperoleh oleh peneliti:

A. Subjek yang memiliki gaya kognitif Field Independent cenderung memiliki proses berfikir konseptual.

1) Soal no 1 bagian (a)

a) FI14

Dalam mengerjakan soal tes no 1 bagian (a), subjek dengan gaya kognitif Field Indpendent (FI14) memiliki proses berpikir konseptual. Karena di sini subjek dapat mampu mengungkapkan dengan kalimat sendiri apa yang diketahui dalam soal (K1.1), mampu mengungkapkan dengan kalimat sendiri apa yang ditanya dalam soal (K1.2) Subjek juga cenderung menggunakan konsep (kombinasi dan permutasi) yang sudah dipelajari walaupun tidak lengkap (K2.3) dan subjek mampu menentukan langkah-langkah yang ditempuh dalam menyelesaikan soal (K1.4). sehingga subjek memiliki proses berpikir konseptual.

b) FI7

Dalam menyelesaikan soal no 1 bagian (a), subjek dengan gaya kognitif Field Indpendent (FI7) memiliki proses berpikir konseptual. Karena di sini subjek dapat mampu mengungkapkan dengan kalimat sendiri apa yang diketahui dalam soal (K1.1), mampu mengungkapkan dengan kalimat sendiri apa yang ditanya dalam soal (K1.2) Subjek juga cenderung menggunakan konsep (kombinasi dan permutasi) yang sudah dipelajari walaupun tidak lengkap (K2.3) dan subjek mampu menentukan langkah-langkah yang ditempuh dalam menyelesaikan soal (K1.4). sehingga subjek memiliki proses berpikir konseptual.

2) Soal no 1 bagian (b)

a) FI14

Dalam menyelesaikan soal no 1 bagian (b), subjek dengan gaya kognitif Field Indpendent (FI14) memiliki proses berpikir konseptual. Hal ini dapat terlihat ketika subjek mampu mengungkapkan dengan kalimat sendiri apa yang diketahui dalam soal (K1.1). Subjek juga mengungkapkan dengan kalimat sendiri apa yang ditanya dalam soal (K1.2) Subjek cenderung menggunakan konsep (kombinasi dan permutasi) yang sudah dipelajari walaupun tidak lengkap (K2.3) dan subjek mampu menentukan 
langkah-langkah yang ditempuh dalam menyelesaikan soal (K1.4). sehingga subjek memiliki proses berpikir konseptual.

b) FI7

Dalam menyelesaikan soal no 1 bagian (b), subjek dengan gaya kognitif Field Indpendent (FI7) memiliki proses berpikir konseptual. Karena di sini subjek dapat mampu mengungkapkan dengan kalimat sendiri apa yang diketahui dalam soal (K1.1), mampu mengungkapkan dengan kalimat sendiri apa yang ditanya dalam soal (K1.2) Subjek juga cenderung menggunakan konsep (kombinasi dan permutasi) yang sudah dipelajari walaupun tidak lengkap (K2.3) dan subjek mampu menentukan langkah-langkah yang ditempuh dalam menyelesaikan soal (K1.4). sehingga subjek memiliki proses berpikir konseptual.

\section{3) Soal no 2}

a) FI14

Dalam menyelesaikan soal no 2 subjek dengan gaya kognitif Field Indpendent (FI14) memiliki proses berpikir komputasional. Hal ini dapat terlihat ketika subjek mampu mengungkapkan dengan kalimat sendiri apa yang diketahui dalam soal (K1.1). Subjek juga mengungkapkan dengan kalimat sendiri apa yang ditanya dalam soal (K1.2). Namun, cenderung lepas dari konsep permutasi yang sudah dipelajari (K3.3) dan juga tidak mampu mengungkapkan langkah-langkah yang ditempuh dalam menyelesaikan soal (K3.4). Sehingga subjek memiliki proses berpikir komputasional.

b) FI7

Dalam menyelesaikan soal no 2 subjek dengan gaya kognitif Field Indpendent (FI7) memiliki proses berpikir komputasional. Hal ini dapat terlihat ketika subjek mampu mengungkapkan dengan kalimat sendiri apa yang diketahui dalam soal (K1.1). Subjek juga mengungkapkan dengan kalimat sendiri apa yang ditanya dalam soal (K1.2). Namun, cenderung lepas dari konsep permutasi yang sudah dipelajari (K3.3) dan juga tidak mampu mengungkapkan langkah-langkah yang ditempuh dalam menyelesaikan soal (K3.4). Sehingga subjek memiliki proses berpikir komputasional.

B. Subjek yang memiliki gaya kognitif Field Dependent cenderung memiliki proses berfikir konseptual.

1) Soal no 1 bagian (a)

a) FD19

Dalam mengerjakan soal tes no 1 bagian (a), subjek dengan gaya kognitif Field Dedpendent (FD19) memiliki proses berpikir konseptual. Karena di sini subjek dapat mampu mengungkapkan dengan kalimat sendiri apa yang diketahui dalam soal (K1.1), mampu mengungkapkan dengan kalimat sendiri apa yang ditanya dalam soal (K1.2) Subjek juga cenderung menggunakan konsep (kombinasi dan permutasi) yang sudah dipelajari walaupun tidak lengkap (K2.3) dan subjek mampu menentukan langkah-langkah yang ditempuh dalam menyelesaikan soal (K1.4). sehingga subjek memiliki proses berpikir konseptual.

b) FD2

Dalam menyelesaikan soal no 1 bagian (a), subjek dengan gaya kognitif Field Indpendent (FD2) memiliki proses berpikir konseptual. Karena di sini subjek dapat mampu mengungkapkan dengan kalimat sendiri apa yang diketahui dalam soal (K1.1), mampu mengungkapkan dengan kalimat sendiri 
apa yang ditanya dalam soal (K1.2) Subjek juga cenderung menggunakan konsep (kombinasi dan permutasi) yang sudah dipelajari walaupun tidak lengkap (K2.3) dan subjek mampu menentukan langkah-langkah yang ditempuh dalam menyelesaikan soal (K1.4). sehingga subjek memiliki proses berpikir konseptual.

2) Soal no 1 bagian (b)

a) FD19

Dalam menyelesaikan soal no 1 bagian (b), subjek dengan gaya kognitif Field Dependent (FD19) memiliki proses berpikir komputasional. Hal ini dapat terlihat ketika subjek tidak mampu mengungkapkan dengan kalimat sendiri apa yang diketahui dalam soal (K3.1). Namun, subjek mengungkapkan dengan kalimat sendiri apa yang ditanya dalam soal (K1.2). Selain itu, Subjek cenderung lepas dari konsep permutasi yang sudah dipelajari (K3.3) dan juga tidak mampu mengungkapkan langkah-langkah yang ditempuh dalam menyelesaikan soal (K3.4). Sehingga subjek memiliki proses berpikir komputasional.

b) FD 2

Dalam menyelesaikan soal no 1 bagian (b) subjek dengan gaya kognitif Field Dependent (FD2) memiliki proses berpikir komputasional. Hal ini dapat terlihat ketika subjek mampu mengungkapkan dengan kalimat sendiri apa yang diketahui dalam soal (K1.1). Subjek juga mengungkapkan dengan kalimat sendiri apa yang ditanya dalam soal (K1.2). Namun, cenderung lepas dari konsep permutasi yang sudah dipelajari (K3.3) dan juga tidak mampu mengungkapkan langkah-langkah yang ditempuh dalam menyelesaikan soal (K3.4). Sehingga subjek memiliki proses berpikir komputasional.

3) Soal no 2

a) FD19

Dalam menyelesaikan soal no 2, subjek dengan gaya kognitif Field Dependent (FD19) memiliki proses berpikir konseptual. Karena di sini subjek mampu mengungkapkan dengan kalimat sendiri apa yang diketahui dalam soal (K1.1). Namun, subjek tidak sepenuhnya mampu mengungkapkan dengan kalimat sendiri apa yang ditanya dalam soal (K2.2). Subjek cenderung menggunakan konsep permutasi yang sudah dipelajari (K1.3) dan subjek mampu menentukan langkah-langkah yang ditempuh dalam menyelesaikan soal (K1.4). sehingga subjek memiliki proses berpikir konseptual.

b) FD 2

Dalam mengerjakan soal tes no 2, subjek dengan gaya kognitif Field Dependent (FD2) memiliki proses berpikir semikonseptual. Karena disini subjek tidak sepenuhnya mampu mengungkapkan dengan kalimat sendiri apa yang diketahui dalam soal (K2.1). Namun, subjek mampu mengungkapkan dengan kalimat sendiri apa yang ditanya dalam soal (K1.2). Subjek juga cenderung menggunakan konsep permutasi yang sudah dipelajari meskipun tidak lengkap (K2.3) dan subjek juga tidak sepenuhnya mampu mengungkapkan langkah-langkah yang ditempuh dalam menyelesaikan soal (K2.4). Sehingga subjek memiliki proses berpikir semikonseptual.

Berdasarkan uraian diatas terdapat proses berpikir konseptual, semikonseptual dan komputasional. Hal ini berdasarkan perdapat Zuhri, Zuhri membagi proses berpikir menjadi 3 yaitu proses berpikir konseptual adalah proses berpikir yang selalu menyelesaikan soal dengan menggunakan 
konsep yang telah dimiliki berdasarkan hasil pelajarannya selama ini, proses berpikir semikonseptual proses berpikir yang cenderung menyelesaikan suatu soal dengan menggunakan konsep tetapi mungkin karena pemahamannya terhadap konsep tersebut belum sepenuhnya lengkap maka penyelesaiannya dicampur dengan cara penyelesaian yang menggunakan intuisi dan proses berpikir komputasional [13]. Proses berfikir konseptual cenderung mengerjakan sesuai dengan prosedur yang ada. Hal ini memiliki kesamaan dengan proses berfikir konvergen. Menurut Ningsih [14] siswa dengan berfikir konvergen cenderung focus pada satu cara yang dipahami saja. Menurut Lailatul Mubarokah [17] Komputasional adalah proses berpikir yang pada umumnya menyelesaikan suatu soal tidak menggunakan konsep tetapi lebih mengandalkan intuisi, akibatnya siswa sering melakukan kesalahan dalam menyelesaikan masalah. Subjek yang memiliki gaya kognitif Field Indpendent cenderung mempunyai proses berpikir konseptual begitupula dengan subjek yang memiliki gaya kogitif Field Dependent cenderung memiliki proses berpikir konseptual [18].

\section{SIMPULAN DAN SARAN}

Proses berpikir mahasiswa semester IVA Program Studi Pendidikan Matematika IAIM NU Metro Lampung yang bergaya kognitif Field Independent cenderung memiliki proses berpikir konseptual. Proses berpikir konseptual adalah proses berpikir yang selalu menyelesaikan soal dengan menggunakan konsep yang telah dimiliki berdasarkan hasil pelajarannya selama ini. Proses berpikir mahasiswa semester IVA Program Studi Pendidikan Matematika IAIM NU Metro Lampung yang bergaya kognitif Field Dependent cenderung memiliki proses berpikir konseptual. Proses berpikir konseptual adalah proses berpikir yang selalu menyelesaikan soal dengan menggunakan konsep yang telah dimiliki berdasarkan hasil pelajarannya selama ini. Kepada peneliti yang ingin melakukan penelitian serupa, hendaknya lebih memperketat pengawasan kepada mahasiswa saat mengerjakan soal. Hal ini bertujuan untuk mengurangi kesalahan dalam mengetahui proses berpikir mahasiswa. Selain itu, hendaknya selalu melakukan wawancara kepada mahasiswa setelah mahasiswa menyelesaikan soal-soal yang diberikan oleh peneliti. Hal ini bertujuan untuk membantu peneliti dalam mengetahui penyebab kesalahan mahasiswa dalam menyelesaikan soal. Kemudian, hendaknya selalu menggunakan validator untuk memvalidasi instrumen-instrumen yang akan digunakan dalam penelitian. Hal ini bertujuan untuk menghindari kesalahan dalam penafsiran mahasiswa untuk menyelesaikan soal.

\section{DAFTAR PUSTAKA}

[1] Herman Hudojo, Pengembangan Kurikulum Dan Pembelajaran Matematika. Malang: Tidak diterbitkan, 2015.

[2] Oemar Hamalik, Kurikulum dan Pembelajaran. Jakarta: PT Bumi Aksara, 2014.

[3] Zainal Arifin, Evaluasi Pembelajaran. Bandung: PT Remaja Rosdakarya, 2009.

[4] Alex Sobur, Psikologi Umum. Bandung: Pustaka Setia, 2013.

[5] Nasution, Berbagai Pendekatan Dalam Proses Belajar Mengajar. Jakarta: Bumi Aksara, 2016.

[6] Departemen Agama RI, Al-Qur'an dan Terjemahannya. Surabaya: Mekar, 2014.

[7] Ruseffendi, Pengantar kepada Guru Mengembangkan Kompetensinya dalam Mengajar Matematika untuke Mengembangkan CBSA. Bandung: Tarsito, 1991. 
[8] Rina Agustina and Nurul Farida, "Proses Berpikir Siswa SMA dalam Menyelesaikan Masalah Matematika Ditinjau dari Tipe Kepribadian Phlegmatis," UMM, vol. 4, no. 1, 2015.

[9] Desmita, Psikologi Perkembangan Peserta Didik. Bandung: PT. Remaja Rosdakarya, 2014.

[10] Wowo Sunaryo Kuswana, Taksonomi Berpikir. Bandung: PT Remaja Rosdakarya, 2011.

[11] Sudarman, "Proses Berpikir Siswa Quitter Pada Sekolah Menengah Pertama Dalam Menyelesaikan Masalah Matematika," Universitas Tudalako, 2011.

[12] M. S. Anwar, "Efektifitas Pembelajaran PBL (Problem Based Learning) Terhadap Kemampuan Berpikir Kritis Dan Kreatif Siswa Materi Tiga Dimensi,” masters, Universitas Terbuka, 2015.

[13]Zuhri D, "Proses Berfikir Siswa Kelas II SMPN16 Pekanbaru dalam Menyelesaikan Soal-soal Perbandingan Senilai dan Berbalik Nilai," Pascasarjana MIPA, 2009.

[14] Ningsih, E. F., "Proses Berpikir Mahasiswa dalam Pemecahan Masalah Aplikasi Integral Ditinjau dari Kecemasan Belajar Matematika (Math Anxiety)," Iqra Educ. J., vol. 1, no. 2, pp. 191-217, 2017.

[15] Kepner, MD and Neimark, ED, "Test-retest Reliability and Differensial Pattern of Score Change on the Group Embedded Figured Test," J. Pers. Soc. Psychol., vol. 46, no. 6.

[16] M. B. Miles and Huberman, Qualitative Data Analysis a Sourcebook of New Methods. London: SAGE Publication Ltd, 1995.

[17] Lailatul Mubarokah, "Proses Berfikir Siswa dalam Menyelesaikan Soal Cerita Ditinjau Berdasarkan Kemampuan Matematika," 2013.

[18] Hamzah B. Uno, Orientasi Baru Dalam Psikologi Pembelajaran. Jakarta: PT Bumi Aksara, 2012. 